\title{
The place of amenity grass seed production
}

\author{
G. S. Robinson \\ New Zealand Turf Culture Institute. Palmerston \\ North
}

\begin{abstract}
In recent years the supply of seed of local types of fine turf grasses has decreased. This has resulted in the need for the importation of overseas cultivars of browntop, creeping bent grass and red fescue. These have generally proved to be very effective in producing high-quality turf.

The coarser types of turf used in sportsfields for football and cricket are ideally ryegrass-dominant Fine-leaved perennial ryegrasses have been developed overseas. and experimental plantings of these in New Zealand look very promising.
\end{abstract}

Key words; Amenity grass, New Zealand, Agrostis tenuis, Lolium perenne. Agrostis palustris. Fesiuca rubra.

\section{INTRODUCTION}

The place of amenity grass seed development and production is dependent on a number of factors.

(a) The future of the industry in terms of types of turf, of new areas to be established and old areas to be renovated of improved.

(b) The extent of the demand for amenity grass cultivars that have been derived from New Zealand material.

(c) The ability of New Zealand producers to obtain worthwhile yields of seed from New Zealand cultivars. This factor is one that will be dealt with by the other speakers in this session.

(d) The demand for multiplication of overseas amenity cultivars which could resuit in an earlier release of new cultivars.

This paper presents the changing scene in turf culture on which will depend the future prospects for amenity grass seed production.

The Future OF THE INDUSTRY

Climatic conditions in New Zealand make it relatively easy to grow grass. whether it be for agricultural purposes or for sport and recreation. However, the types of grass used and the management they receive are very different, and depend largely on their particular usage (Table 1). Amenity turf can be divided into two main types:

(a) Fine turf is required for sports which call for the ball or bowl to run smoothly over the surface of the ground. The necessity for this smoothness is greatest with outdoor bowling greens, but it is also very important with golf greens and cricket pitches. Hockey, and to a lesser degree soccer, should also be played on fine turf, but the degrcc of perfection can be lower.

The most important grasses used for fine turf are Agrostis tentiis Sibth. (browntop). Agrostis palustris L. (creeping bent grass) and Festuca rubra (red fescue including Chewings fescue). Fine-leaved cynodon cultivars have potential in the warmer parts of New Zealand.

Most of the browntop and fine-leaved fescue is used by home owners in the sowing of new lawns. The majority of New Zealanders consider an attractive fine turf lawn essential in the development of their house section, and they prefer to mow to $11 / 2 \mathrm{~cm}$ height or less. In the United States, lawns are kept to about a height of $4 \mathrm{~cm}$ or more (Darrow, 1939), and Poa pratensis L. is one of the main grasses. In New Zealand, susceptibility to rust (Puccinia

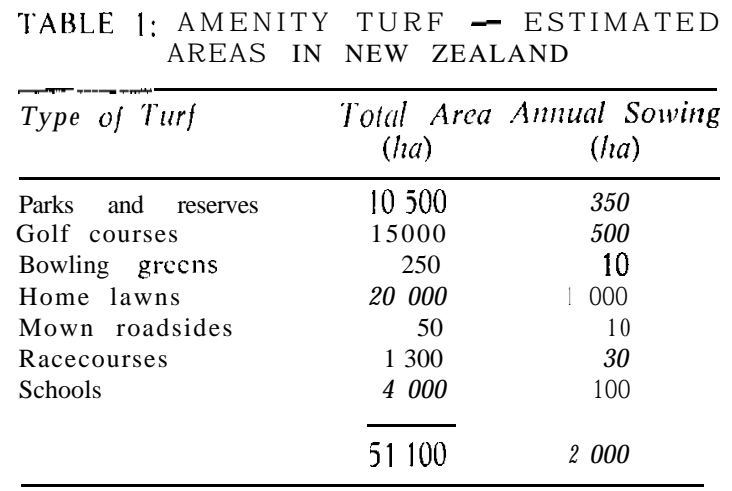


spp.) and an adverse reaction to close mowing preclude its use. Even with the reduced homebuilding programme, approximately 1000 ha/yr are sown in lawns. The seed mixture used is often diluted with crested dogstail (Cynosurus cristatus L.), which is not a desinable lawn grass because it is short-lived and does not form a dense even turf. However, upwards of 200 tonnes of browntop/red fescue mixtures are sold for fawns every year. The quantities used by the 400 golf courses in New Zealand would be much less than this.

A development that has been slow to materialize in New Zealand is the establishment of fawns from sod. Commercial production and the safe of turf enables developers to provide a ready-made turf as soon as building is completed. The success of a sod industry is dependent on a viable house-building industry, and is best suited to areas of high population where cartage costs can be expected to be minimal.

Fine turf is being used less and less on bowling greens as Cotulu tlioicn spp. dioica is gradually taking over and is vegetatively propagated. It is not suitable for other sporting activities.

(b) A large area of sports turf consists of coarser species and is represented in the playing fields controlled by local authorities, racing clubs, education boards and the Education Department. Their main requirement is that the surface stand up to wear, and perennial ryegrass (Lolium perenne L.) is best able to meet this. Unfortunately, 'Grasslands Ruanui', with its low density and coarse texture, does not produce a first-class turf. The inclusion of a small proportion of browntop assists in giving a more complete cover but it is easily ripped out. What is required is a denser, finer-leaved type of ryegrass. Cuftivars with these qualities are available in other temperate countries. Approximately 20000 ha of our coarser sports turfs could be markedly improved by incorporating these cultivars into the present grass cover by direct drilling. Expcriencc has shown the desirability of using a minimum of 100 $\mathrm{kg} / \mathrm{ha}$ of ryegrass when seeding bare areas. The cost of this sphere of work in one of New Zealand's larger cities that has an advanced outlook on sportsficld maintenance is $\$ 5000$ a year for seed alone. If schools and other local authorities were to operate on a similar scale the worth of the industry would increase manyfold. Roadside verges and airfields are unlikely to require anything but small quantities of seed for their maintenance.

\section{New Zealand Sources of Seed}

Until about 10 years ago the supply of fine turf seed from New Zcaland sources was ample. Since then the production from local types has declined mainly because of stock farming development in the seed-growing areas. Importations of seed from overseas have become necessary to meet local demands (Shildrick, 1972). These imported cuftivars are mainly the result of selection and plant breeding and are superior in quality to the unselected N.Z. browntop and N.Z. Chewings fescue. During this same period Dr Rumbal1 has been making selections from New Zealand material. Testing of these so far has been limited, but results appear promising. They are equal to the best of the overseas lines, and there seems no reason why they should not ultimately replace imported ones.

In view of the promising experimental results with turf-type rycgrasses from overseas (Beard, 1973), a selection programme of fineleaved lines of New Zealand origin has been in progress for several years at Grasslands Division. The impact of this programme could be far greater than for the fine-turf species as the area of usage is more extensive. It could depend also on the development of an export trade which, in view of the growth of importance of amenity arcas in the temperate world, has possibilities.

Altogether the scope for further expansion of the seed trade in turf ryegrasses is good. Renovation of coarse-turf areas has generally been neglected, but with increased play the maintenance of a grass cover is going to depend more on cfficient renovation in which seeding is an integral part.

\section{REFERENCES}

Bcard. I. B.. 1973. Tur/grass: Science and Culture. Prentice-Hall. Inc.

Darrow, R. A., 1939. Bot. Gaz., 101: 109.

Shildrick. J. P., 1972. J. Sports Turf Res. Inst., 48: 44. 